\title{
THE ECLECTIC APPROACH ON ONE-TO-ONE TEACHING INDONESIAN FOR FOREIGNER
}

\author{
Hanna Sundari \\ Faculty of Language and Art, Universitas Indraprasta PGRI \\ hanna.sundari@gmail.com
}

\begin{abstract}
Abstrak
Bahasa Indonesia banyak diminati dan dipelajari oleh para penutur asing dengan berbagai alasan dan tujuan sehingga pembelajaran Bahasa Indonesia bagi penutur asing (BIPA) semakin mendapat perhatian dan kajian secara luas dalam bidang pembelajaran bahasa asing. Salah satu pendekatan pembelajaran yang dapat diterapkan di kelas bahasa adalah pendekatan eklektik. Artikel ini mendeskripsikan penerapan prinsip-prinsip pendekatan eklektik dalam pembelajaran Bahasa Indonesia bagi penutur asing khususnya untuk pembelajaran satu-satu. Partisipan dalam penelitian ini adalah satu orang tutor dari Indonesia dan satu murid asal Australia yang melaksanakan pembelajaran selama 14 pertemuan. Dengan menggunakan desain penelitian kualitatif deskriptif, catatan guru, kertas kerja dan materi ajar kemudian dikumpulkan, dianalisis dan diinterpretasikan. Lebih lanjut, kuesioner terbuka juga diberikan untuk mencari tahu bagaimana pendekatan eklektik diterapkan. Temuan penelitian menunjukkan praktek-praktek eklektik meliputi tugas komunikatif, dialog teratur, penggunaan materi ajar otentik, perpaduan keterampilan bahasa dan komponen bahasa, juga tata bahasa deduktif dan pengembangan kosakata. Dan ini merupakan kombinasi dari tiga metode pembelajaran yang sudah dikenal.
\end{abstract}

Kata Kunci: pendekatan eklektik, BIPA, pembelajaran satu-satu

\begin{abstract}
Indonesian has been considerably preferred and extensively taught by many foreigners for various causes and purposes so that its teaching (Indonesian for foreigners or BIPA) has attracted more attention and wide studies in the field of foreign language instruction. One of approaches in language classroom is eclectic approach. This paper tries to describe the implementation of the principles of eclectic approach for one-to-one teaching Indonesian for foreigner. The participants were one Indonesian tutor and one Australian tutee who managed 14 meetings for teaching sessions. Using descriptive qualitative research design, teacher/course notes, worksheets, and learning materials were collected, analyzed, and interpreted. Moreover, open-ended questionnaire was to gather of how the approach was implemented. The findings show that the eclectic practices cover communicative tasks, regular dialogues, using authentic materials, integration of language skills and component as well as deductive grammar and vocabulary building. And it is a combination of three well-known language teaching methods.
\end{abstract}

Keywords: eclectic approach, BIPA, one-to-one teaching 


\section{INTRODUCTION}

Indonesian for foreigners (BIPA, bahasa Indonesia bagi penutur asing) can be defined as a language learning program particularly managed to present a class for foreign students to learn Indonesian (Suyitno, Susanto, Kamal, \& Fawzi, 2017). Many foreigners from countries around the world want to learn Indonesian because of some reasons and various purposes. Suyitno (Suyitno et al., 2017) summed up that getting knowledge about Indonesian language, doing research, working purposes, and staying for a period of time are several purposes of foreigners to take Indonesian course. Moreover, supporting diplomacy and enhancing knowledge and culture of Indonesia also motivate foreigners to learn Indonesian (Andayani, 2016). The high demand of Indonesian courses may result from the tourism, business, investment and work factors, as stated by Sudini (2008 in (Gusnawaty \& Nurwati, 2019). To support this view, Mediyawati, Lustyantie, \& Emzir, (2019) reported that, by 2017, foreign worker in Indonesia reach more than 85.000 people who stay and need to communicate using Indonesian. Not only the number of workers, several foreign companies located in Indonesia require the employee to have ability to speak Indonesian for business communication. Related to getting cultural and economic motives, Hyun (2015), a BIPA practitioner from South Korea, stated that Korean people have desire to learn Indonesian because they want to explore its language and culture through BIPA programs in some universities in Indonesia; moreover, the rapid growth of Indonesian economy, with GDP $6.2 \%$ in $2010,6.5 \%$ in $2011,6.3 \%$ in 2012, and $5.8 \%$ in 2013 and the numbers better than Korean has (Hyun, 2015), may cause Korean people are interested in learning Indonesian. As a consequence, language courses/centres which offer Indonesian will usually be full of foreign students.

The existence of BIPA, also known as TISOL (Teaching Indonesian for Speakers of Other Languages), has tremendously mounted nowadays not only in its home, Indonesia, but overseas as well. Jazeri \& Maulida (2018) stated that, in 2018, not less than 76 language institutions have opened BIPA services in Indonesia, at the same time, 179 institutions have also offered Indonesian courses all over the world. Moreover, Sari, Sutama and Utama (2016 cited in Gusnawaty \& Nurwati, 2019) reported that Indonesian are formally taught in at least 72 countries, such as Morocco, German, Poland, Australia, The U.S, Canada, Vietnam, Korea, Thailand, and many more. In Thailand, Indonesian has become one of the most preferred subjects and has been taught in eight universities including Nerusuan University, Chulalongkorn University, Mae Fah Luang University, and Ciangmai University (Tiawati, 2016). According to Hyun (2015), three universities and several private language courses have provided Indonesian classes because of high demand. Moreover, Indonesian course programs have also been opened in at least 46 countries either at universities or embassies and consulates of Republic of Indonesia (Azizah, Widodo and Lestari, 2012 cited in Hardini, Setyarini, \& Harto, 2019). Meanwhile, in Australia, Indonesian is one of the most well-liked to learn among people, together with Mandarin, Chinese, and Italian (Dodiangga, 2017 cited by Hardini et al., 2019). In 2008, Department of Education, Employment and Workplace Relations, Government of Australia reported that around 5.6\% of total student population, approximately 191.316 students, has learned Indonesian at primary and secondary levels of education (Hardini et al., 2019); besides, Indonesian has formally been taught at least in 500 schools in Australia (Andayani, 2016). In the other words, the number of BIPA learners has highly increased either in its home or overseas, in both formal education such as, schools and universities and private language institutions. 
In the line with the wide expansion of BIPA, the research and studies have been widely conducted related to teaching and learning of BIPA. Some of them are studies by Andayani (2016) and Suyitno et al. (2017). To improve language skills and introduce local culture, Andayani (2016) implemented the integrative model of learning through action research. While, in 2017, Suyitno et al. (2017) have investigated the cognitive learning strategies by foreign students in learning Indonesian. Moreover, Arumdyahsari, Hs, \& Susanto (2016) have developed BIPA's teaching materials in intermediate level with reference ACTFL, integrative learning model, and communicative with design eligibility notice, presentation, content, language, and application. In 2019, Gusnawaty \& Nurwati (2019) have proposed a learning model of Bahasa Indonesia to improve communicative competences based on local intercultural politeness in South Sulawesi. Then, Mediyawati et al., (2019) developed a new framework learning materials using multicultural domestic foreign workers' characters for business communication purposes.

The research on the issues of BIPA have been remarkably carried out mostly in developing learning model and materials for Indonesian classes. However, it is still rare study that discusses and describes the teaching and learning for individual class and oneto-one learning system. In fact, a lot of Indonesian courses are held for private and individual sessions instead of class and institutions. Looking at what the author experienced when staying abroad, the demand for teaching Indonesian taught by Indonesian people was quite high. It was then managed privately without any agency or institution. It could not be denied that being a BIPA teacher/instructor does not require a degree from university or certificate from formal BIPA institution. Many foreign students in Indonesia become instructors to teach Indonesian when they come back to their countries due to their ability to speak Indonesian (Jazeri \& Maulida, 2018). As a consequence, teacher competence to teach is questionable and the learning materials are not available. Therefore, to be more detail for private and one-to-one teaching session, the teaching approach should be carefully selected.

In the recent times, when teachers find methods inadequate to meet the challenges of the practice everyday teaching, they try to derive a 'method' of their own and call it eclectic method (Kumaravadivelu, 2006). The root word of eclecticism is derived from 'elect' which means to choose or to pick up; it covers a process of ideological selection, evaluation, discrimination, synthesis and then used in for teaching learning process in order to get targeted learning outcomes (Obot \& Essien, 2014). Meanwhile, in the field of language teaching, Kumar (2013 cited by Alharbi, 2017; Febriyanti, Hadi, \& Saputri, 2018; Mwanza, 2017) stated that the eclectic method is a rich combination of multiple activities, including participatory, communicative, and situational approaches. Using various methods for language classes is as a consequence of variety of needs and heterogeneous students. As wrote by Popova (2001), eclecticism addresses to cater a wide variety of individual preferences, abilities, interest, needs, and learning objectives. Moreover, Li (2012 cited in Biloon 2016) viewed that there is no single techniques or method to teach all skills and to specific learner's needs. In addition, a single traditional approach/method has a narrow theoretical basis, a delimited set of activity and inflexibility (Gilliland, James, and Bowman, 1994 cited in Mwanza, 2017). To response on these views, eclectic approach provides a pluralistic, inclusive, all-encompassing and comprehensive approach of teaching that different methods are systematically and logically combined and used eclectically to meet the learner's needs (Larsen-freeman, 2004 cited in Najeebullah, Tabassum, \& Irfanullah, 2018). Eclectic approach is not just a random combination of different methods to teach, it serves a balance development of all 
language skills (Wali, 2009) and mixes the good sides of the selected teaching techniques (Kurniasih \& Rahmawati, 2018). As stated by River (1981 in Suleman \& Hussain, 2016), eclectic system permits the language teachers to adopt the all popular language teaching methods for their classroom procedures. Therefore, the teacher who applies this approach should have high knowledge of language teaching methods and enables to combine and execute them for classroom activity.

Due to the combination from various of language teaching methods, eclecticism takes possession of certain principles. Flexibility becomes the main characteristic of eclecticism. The flexibility means that teacher has a chance to choose any aspect or different kinds of teaching methods that suit to the learning goal (Ali, 1981, in Mwanza, 2017a). When each teacher can flexibly select and apply two or more language methods based on the needs, it leads to the particularity and locality of language teaching. Tarone and Yule (1989 in Popova, 2001) wrote that eclecticism covers a philosophy of local solution to local problems. In the other words, this approach depends on the teacher, learner and materials in culture and learning context (Mwanza, 2017a). What the learner needs for learning becomes the centre of teaching since a particular learner has a particular learning situation.

The studies concerning to application of eclecticism have been widely conducted in language classrooms. In 2007, Xiao-yun, Zhou, \& Dai (2007) have proved that eclecticism is extensively practised by College English teachers and is warmly welcome by the students. And then, a principled eclectic approach has been proposed for teaching EFL writing in Taiwan (Min, 2009) as well as the principles of eclecticism are applied in developing writing materials or Indonesian EFL learners (Kurniasih \& Rahmawati, 2018). In 2017, (Suparman, 2017) combined grammar-translation method and genrebased approach to teach EFL writing classes. Research by Khoiriyah (2012) and Rifa'i (2015) have showed that eclectic approach is provenly effective for teaching Arabic. Moreover, eclectic approach is also recommended for teaching English communication skill at all levels of education, particularly in elementary school, as suggested by Najeebullah et al. (2018). However, little is known the implementation of eclecticism for language course particularly for one-to-one teaching system which adheres flexibility and focuses on learner's needs. Therefore, this paper aims at describing the application of eclectic approach for teaching Indonesian one-to-one system.

\section{RESEARCH METHOD}

This current research paper aims at describing of how eclectic approach has been implemented for teaching Indonesian for foreigner using one-to-one system. The learnerparticipant, as a tutee, was one native Australian woman, the age of 43 years old. She took Indonesian course and preferred one-to-one system for several reasons. Meanwhile, the teacher-participant, also the first author, was the tutor who managed 14 teaching sessions from December 2018 to June 2019. Each session lasted around 2 hours and it was held once a week at St. Kilda's Library.

Furthermore, non-structured interview, open-ended questionnaire, and documents (Gay, Mills, \& Airasian, 2012) were used in collecting data. There were several meetings for pre-course. During these sessions, observation and non-structured interview were carried out to get the needs, including her language proficiency, motivation, and expectation on learning Indonesian as well as the previous learning activities. While, the questions were exploring her perceptions and evaluation of the course she attended with the instructor. The documents were the scheme of work, teacher notes, learning materials, 
worksheets, and assignments that were used and produced during the sessions. Those were to discover the learning activities and practices. The gathered data were then coded, analysed and classified to see the common practices. The conclusions, at last, were drawn from the research findings and results.

\section{RESULT AND DISCUSSION}

After collecting and analysing data, they then are both presented and discussed into two major points: 1) learner's need and learning situations, and 2) eclectic practices during the course, as follow.

\section{Learner's needs and Learning Situations}

From the pre-course meeting, it is known that the learner participant has been learning Indonesian for around two years. She is able to apply some basic words related to personal and family topics, such as part of body, number, colour, yes/no questions, introduction herself. Therefore, it is assumed that she predictably is as a beginner level learner who belongs to Level A2, based on English Profile: Introducing the CEFR for English (2011). She is 43 years old when taking the course; as an adult learner, she is able to stay focus for quite a long time and understand abstract concepts and rules (Brown, 2007). Having a master degree from one university in Melbourne, she is now taking care of three children. Not only joining a language course, she also takes an online course in nutrition and health. She said, on the questionnaire, that her motivation to learn Indonesian because she loves the country and wants to frequently visit Indonesia and communicate with local Indonesian people, as in the excerpt below.

Saya memutuskan untuk belajar bahasa Indonesia karena saya mencinta negara ini; saya ingin berbicara dengan orang local dan, karena saya ingin menantang diri saya sendiri untuk belajar bahasa lain (Q2). (I decide to learn Indonesian because I love this country; I want to speak to local people, and because I want to challenge myself to learn other language).

From her motivations and several courses she takes, it seems that she is kind of high motivated learner; in which motivation may lead and determine to success of language learning (Williams \& Burden, 2007).

Concerning to the course program, it was held in learning hub at St. Kilda's library every Tuesday from December 2018 to June 2019. The meetings were not always in a regular schedule. Once the school holiday or term holiday came, the course session would be off. Allocated around two hours, the course was managed by one tutee and one tutor. The learner-participant prefer private teaching system because she requires for intense language learning with flexible and negotiated schedule.

\section{Eclectic Practices}

\section{Communicative activities/tasks}

Based on the documents, it was discovered that activities can promote the use of communication between tutee and the tutor as one of the major activities all over the sessions. Communicative activities cover the use of oral language particularly to embrace speaking and listening skills. The following are the activities found during the sessions.

Give one sample of park/taman and describe it. Student describes "Dendy Park" near her house (location, function, situation, history, etc.). (4.3) 
Compare and describe orally two tourism places. Student describes Adventure Park in Melbourne and Water Boom in Bali. She compares location, facilities, services, ticket price, etc. (5.5)

Describe one of the monuments that the student knows with pointing out to the location, function, visitors, historical values, etc. She describes orally Shrine of Remembrances in Melbourne. (6.5)

Give direction to the site asked by the instructors by using the expression "saya akan ke rumah sakit, kemana saya harus berjalan? Kemudian, saya mau ke kantor polisi, kemana saya harus berjalan?" (8.2)

Describe her experience in eating instant noodle Indomie. (10.5)

Instructor gives the student one piece of Indomie instant noodle and asks her to cook it at home and write the steps and review it. (10.6)

$\mathrm{S}$ shares her experiences in expressing sympathy in her cultures. (12.6)

Oral practices applied in the sessions were mostly to describe places and personal experiences the learner has undergone. Some of them were guided by model text or dialog sample. It seems that these activities are grounded by the communicative principles in teaching language. As Finocchiaro and Brumfit offered the lesson outline for beginning level using Communicative Language teaching procedures (Richards \& Rodgers, 2001).

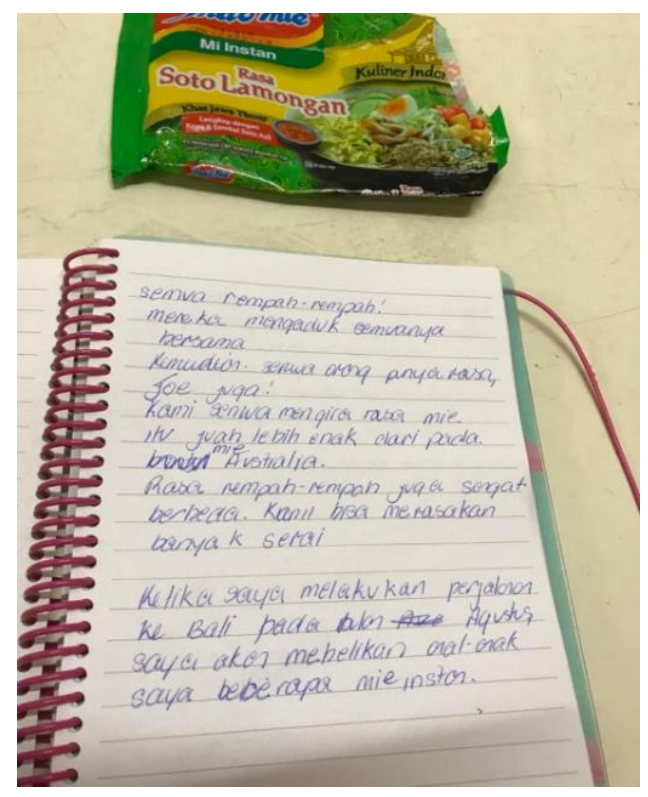

Figure 1 Sample of Written Assignment: How to cook Indomie instant noodle

They stated that oral practice and basic communication expression in the dialogues from guided to freer communication activities are several CLT procedures. By doing these activities, learner feels stimulated to use and produce the variety of language which focuses more on content instead of form (Harmer, 2005). The freedom to use of language learner has on her own can be seen on the written assignment to cook Indomie instant noodle and write the review (Fig. 1). The Learner-participant is able not only using transitional words for chronological orders, such as pertama-tama, setelah itu, kemudian, but also, she extensively modifies and produces other language forms, such as verb menambahkan, mengeringkan, membelikan and determiner sebagian besar. 
Moreover, communicative activity on the course can also be guided by the principles of task framework. In fact, all the activities are stated to force the learning to interact the language so that it will be clear relation between linguistic form, communicative function and semantic meaning (Nunan, 2004). As excerpt 8.2, by looking a map, learner was asked to give direction to one place. This activity stimulates the learner to use functions, such as asking for and giving direction, as well as implicitly used the linguistic form of questions and imperative and their meaning and use in real communication.

\section{Focusing on fluency through dialogues}

Dialogues became the most prominent activities along the course. In each session, the tutor and tutee always greeted, conversed and discussed each other before starting the lesson. It lasted at the first thirty minutes of the session. The topics discussed were personal and family issues and the latest issues either in Indonesia or in Australia, as displayed below from the teacher/course notes.

Discussing and conversing about daily/weekend activities, family, etc. Student asks some questions, and so does the teacher. (3.1)

Discuss and converse about family, weekend activity, pregnancy, cupping therapy (bekam), etc. Student asks some questions, and so does the teacher. (5.1)

Discussing and conversing about family, weekend activity, pregnancy, motherhood, etc. Student asks some questions and so does the teacher. Also, teacher describes the steps of cooking Ayam Bakar completed with the photos. (6.1)

Discussing and conversing about family, weekend activity, pregnancy, motherhood, political issues, etc. Student asks some questions and so does the teacher. (11.1)

Discussing and conversing about family, pregnancy, weekend activity, Ramadhan and Idul Fitri activity, Queen's Birthday public holiday. Student asks some questions, so does the teacher. (13.1)

During the course program, dialogues was centred though it was not based on certain communicative functions. The ability to use language effectively and appropriately through oral activities is the targeted goal of learning. This is consistent with the principles of communicative approach in which dialogues, such as yes/no question and answer related to personal experiences, are around communicative functions and the teacher cannot know what language the students will use (Finocchiaro and Brumfit, 1983 in (Richards \& Rodgers, 2001). Therefore, the real language may be used based on the real context, stated by Larsen-Freeman (2000) as authentic language. During the session, the learner-participants was not guided by certain language functions, but she has a free choice of what she said and how to say it. It seems that the principles of communicative language teaching were not fully and strictly adopted and applied for the course. In Communicative Language Teaching (CLT), as mentioned by Larsen-Freeman (2000), though language exercise is not tightly controlled, students need to perform a variety of functions and forms in true communication.

\section{Authentic materials/ Realia}

In several session, the tutor provided the learning materials which were actually not for teaching purposes. Some reading texts were taken from BUSET magazine, such 
as Cerdas Berbelanja Saat Boxing Day (Fig. 2) and Menikmati Indomie di St. Kilda Festival. Indomie instant noodle was also used for learning materials when tutor asked the learner to write the steps of cooking and review it. Moreover, a tour brochure "Jefanda Wisata" from the coursebook Sahabatku Indonesia looks an authentic brochure. At meeting seven, the learner was asked to listen Indonesian popular song entitled "Surat Cinta untuk Starla" by Virgoun and describe her feeling, impression and interpretation after listening it several times.

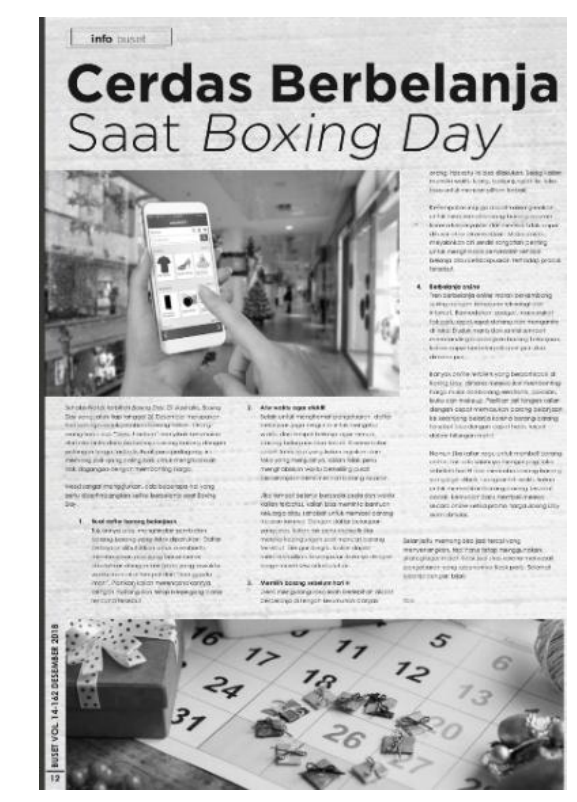

Figure 2 Learning Material from BUSET Magazine

The use of authentic materials, 'from life' materials in the class, is advocated by Communicative Language Teaching as well as Task-based language teaching favors authentic materials in performing authentic task, where possible (Richards \& Rodgers, 2001). These materials are to promote communicative exercises and to build communication into real world. Through materials that are taken from the real situation, the language use and communication can be more natural.

\section{Deductive grammar and Translating exercises}

Deductive grammar is taught by presenting and studying grammar rules, and it is considered one of principal characteristics of the Grammar-Translation Method (Richards \& Rodgers, 2001). During the Indonesian course, the tutee was provided a set of rules of certain grammatical item, and, helped by the tutor, she read, analysed, translated, and practised it in such an isolated sentence to apply how the rules work. For example, on meeting 11, the tutee, assisted by the tutor, read and discussed thoroughly the grammar point Adverb of time in Bahasa Indonesia that was taken from BUSET Magazine (Fig. 3). After that, grammar exercise in the form of translating practices was prepared. 


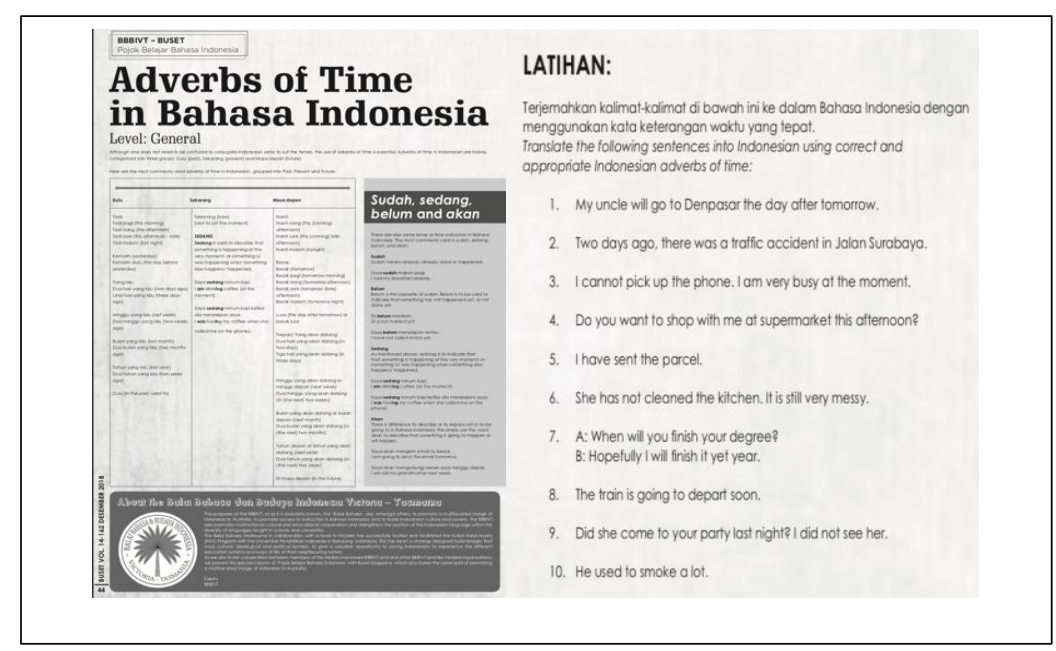

Figure 3 Grammar Item and Exercise from BUSET Magazine

Moreover, another grammar point discussed and practiced explicitly were cause-effect markers, noun phrases, conjunction, negation, commands and prohibitions (Table 1). Explicit presentation of grammar rules was selected as a response of what the learnerparticipant expect in learning language. She stated that she expected to improve writing and speaking skills as well as Indonesian grammar system. Deductive approach occurs when teachers present a clear explanation until the students internalize the rules (Krashen, 1982 in Sik, 2015); teachers consciously teach them and give specific information about language (Nunan, 1991 cited in (Sik, 2015). Teaching grammar deductively is considered more effective than inductive one (Norris and Ortega, 2000 in Jean \& Simard, 2013); similarly, Krashen (1982, in Sik, 2015) said that deductive grammar sounds more reasonable, why make the students guess the rules.

From the Indonesian course, sometimes the presentation of grammar rules then would be followed by oral practice to practise the rules. For example, at meeting 4, both tutee and tutor were taking turn to give examples of Commands and Prohibitions orally. This consistent with what is stated by Jean \& Simard (2013) that, after explanation of a set of rules, it is practiced in different types of exercises, often culminating in communication task or open-ended production.

Table 1 Grammar Points on the Course

\begin{tabular}{l}
\hline \multicolumn{1}{c}{ Grammar points } \\
\hline Cause-effect marker (karena, sehingga) (1.5) \\
Conjunctions (dan, atau, tanpa) dan Noun phrases (2.7-8) \\
Negation/ negative sentence using tidak, bukan, tanpa (3.6) \\
Commands and Prohibitions (4.4) \\
Adverb of time (dulu, sekarang, masa depan) (11.3)
\end{tabular}

Another practice in the Indonesian course was translating exercises as a part of reading activity. Approximately 9 meetings out of 14 were completed by translating activity. For example, on meeting 13, the activities cover reading text entitled "Batik" Unit 9 Budaya from the coursebook (13.2) and translating the text sentence by sentence for each paragraph (13.3). This activity is consistent to principles of Grammar-translation 
Method. In GTM, the sentence has become the basic unit of language practice and the lesson is devoted to translating sentences (Richards \& Rodgers, 2001).

\section{Integrated Language Skills and Vocabulary Building}

The Indonesian course held by the tutor did not clearly distinguish language skills. On the other hand, it integrated several language skills and language component (grammar and vocabulary) in one meeting. On meeting 10, for instance, the tutor combined speaking, reading and vocabulary in discussing text from magazine (table.2).

Table 2 Sample of Course Notes

\begin{tabular}{|c|c|c|c|c|}
\hline $\begin{array}{l}\text { Meeting } \\
10\end{array}$ & $\begin{array}{l}14 \\
\text { May, } \\
2019\end{array}$ & $\begin{array}{l}\text { Discussing } \\
\text { text } \\
\text { "Menikmati } \\
\text { Indomie di St. } \\
\text { Kilda } \\
\text { Festival" } \\
\text { Majalah } \\
\text { BUSET, Vol } \\
\text { 14- 1655 } \\
\text { March } 2019\end{array}$ & $\begin{array}{l}\text { Speaking, } \\
\text { Reading } \\
\text { and } \\
\text { Vocabulary }\end{array}$ & $\begin{array}{l}\text { 1. Discussing and conversing about } \\
\text { family, weekend activity, } \\
\text { pregnancy, motherhood, political } \\
\text { issues, etc. Student asks some } \\
\text { questions and so does the teacher. } \\
\text { 2. Reading and translating the text } \\
\text { sentence by sentence } \\
\text { 3. S feel difficult when reading } \\
\text { words with long syllabus, such as } \\
\text { keberadaan, mencerminkan, } \\
\text { kemungkinan, berkesempatan, } \\
\text { mengungkapkan. } \\
\text { 4. And S seems difficult to } \\
\text { pronounce the sound "-ng" for } \\
\text { example: menantang, panggung, } \\
\text { sangat, pengunjung, } \\
\text { 5. S describes her experience in } \\
\text { eating instant noodle Indomie. } \\
\text { 6. Instructor gives the } S \text { one piece of } \\
\text { Indomie instant noodle and asks } S \\
\text { to cook it at home and write the } \\
\text { steps and review it. }\end{array}$ \\
\hline
\end{tabular}

From the learning materials used in the course, Sahabatku Indonesia (Muliastuti, Marlina, \& Kurniawati, 2016), it can also display the integration of several skills and language component (fig.4). The course does not view that language skill as a discrete component. Though oral practice or speaking activity is the central of the course, it should also be supported by other skills and language component. The integration of all language skills based on the specific learner's need is one of the characteristic of eclectic approach (Biloon, 2016). 


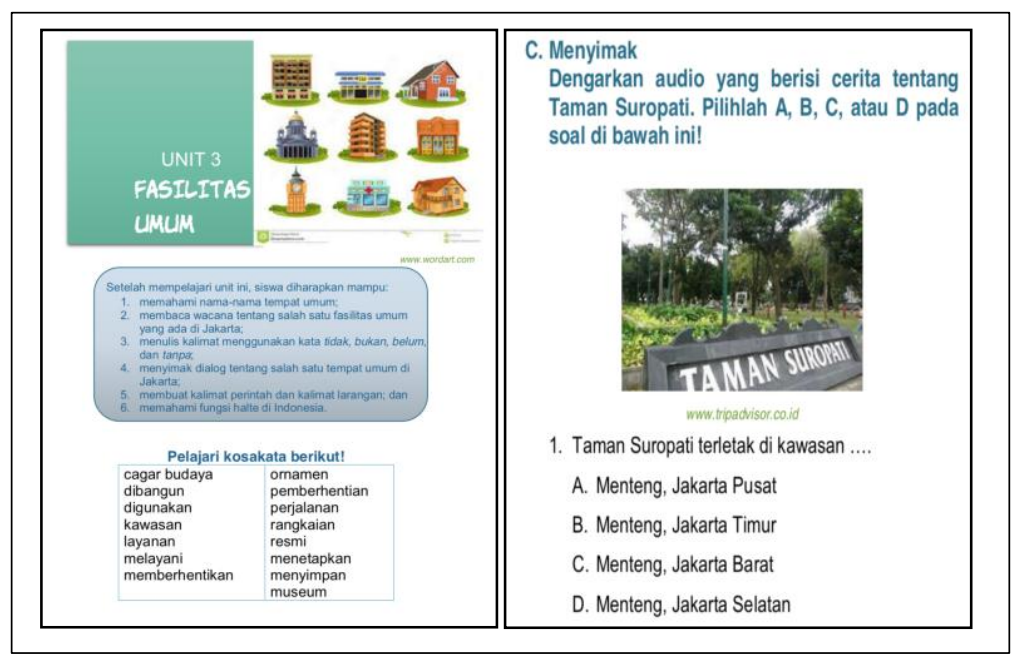

Figure 4 Sample of Learning Material from Sahabatku Indonesia

All in all, the course BIPA program managed by the tutor was implemented eclecticism based on the learner's specific needs in learning Indonesian. The eclectic practices during the session covers the communicative activities/tasks, fluency through dialogues, authentic materials/ realia, deductive grammar and translating exercises, and integration of language skills and vocabulary building. From the eclectic practices implemented on the course, at least, three well-known language teaching methods have grounded the selection of practices. There are Grammar-translation method, Communicative Language Teaching and Task-based language teaching.

\section{CONCLUSION}

This current paper aims at describing the eclectic approach that implemented on BIPA course program for one-to-one teaching system. The course was opened for one Australian woman whose Indonesian proficiency might predictably be as beginner level learner. During 14 meeting encounters, several eclectic practices have been discovered such as communicative tasks, regular dialogues, using authentic materials, integration of language skills and component as well as deductive grammar and vocabulary building.

The BIPA course for one-to-one teaching system is not free from constraints and limitation. The implementation of eclecticism is purely based on the learner and learning needs. The only reason in selecting task, materials and activities is what the learner needs in learning language. Indeed, it should be a teaching philosophy why the teacher does what she does. Therefore, it is advisable to consider the principled eclecticism for future teaching BIPA course for either one-to-one or class-mode teaching system

\section{REFERENCES}

Alharbi, S. H. (2017). Principled eclecticism: Approach and application in teaching writing to ESL/EFL students. English Language Teaching, 10(2), 33. https://doi.org/10.5539/elt.v10n2p33

Andayani, A. (2016). Improving the language skills and local cultural understanding with integrative learning in teaching Indonesian to speakers of other languages ( TISOL ). International Journal of Language and Linguistics, 3(2), 44-53. 
Arumdyahsari, S., Hs, W., \& Susanto, G. (2016). Pengembangan bahan ajar keterampilan berbicara bahasa Indonesia bagi penutur asing tingkat pemula. Jurnal Pendidikan - Teori, Penelitian, Dan Pengembangan, 1(3), 326-337. https://doi.org/10.17977/jp.v1i3.6155

Biloon, J. R. S. (2016). The use of the eclectic method in an English language classroom for learning specific skills. Journal of English Education, 1(2), 140-146.

Brown, H. D. (2007). Teaching by principles: An interactive approach to language pedagogy (p. 491). New York: Pearson Education.

English profile: Introducing the CEFR for English. (2011). Retrieved from http://www.englishprofile.org/images/pdf/theenglishprofilebooklet.pdf

Febriyanti, R. H., Hadi, I., \& Saputri, N. L. (2018). Penerapan penggunaan eclectic method dalam pengajaran bahasa Inggris pada guru SDIT dan SMPIT. Seminar Nasional Dan Diskusi Panel Multidisiplin Hasil Penelitian \& Pengabdian Kepada Masyarakat, 659-667. Jakarta: Unindra PGRI Jakarta.

Gay, L. R., Mills, G. E., \& Airasian, P. W. (2012). Educational research: Competencies for analysis and application (Tenth). https://doi.org/10.1017/CBO9781107415324.004

Gusnawaty, G., \& Nurwati, A. (2019). A learning model of bahasa Indonesia as a foreign language based on local intercultural politeness. Cakrawala Pendidikan, 38(1), 141-155. https://doi.org/10.21831/cp.v38i1.23022

Hardini, T. I., Setyarini, S., \& Harto, S. (2019). Indonesian language assistant program in Australian Schools: Recruitment and selection process. Jurnal Cakrawala Pendidikan, 38(2), 330-342. https://doi.org/10.21831/cp.v38i2.25083

Harmer, J. (2005). The Practice of English language learning. Malaysia: Pearson Education Limited.

Hyun, P. J. (2015). Potensi dan tantangan bahasa Indonesia menuju bahasa internasional. $\begin{array}{lll}\text { Jurnal } & \text { Sosioteknologi, } & 14(1),\end{array}$ https://doi.org/10.5614/sostek.itbj.2015.14.1.2

Jazeri, M., \& Maulida, S. Z. (2018). Hambatan dan harapan pemartabatan bahasa Indonesia. Indonesian Language Education and Literature, 4(1), 52. https://doi.org/10.24235/ileal.v4i1.2493

Jean, G., \& Simard, D. (2013). Deductive versus inductive grammar instruction: Investigating possible relationships between gains, preferences and learning styles. System , 41, 1023-1042. https://doi.org/10.1016/j.system.2013.10.008

Khoiriyah, R. L. (2012). Pengaruh metode eklektik terhadap hasil belajar keterampilan berbicara bahasa Arab siswa kelas X Ma Manahijul Huda Ngagel Dukuhseti Pati. 
Lisanul' Arab: Journal of Arabic Learning and Teaching, 1(1), 1-7.

Kumaravadivelu, B. (2006). Understanding language teaching: From method to postmetod. https://doi.org/10.1016/S0093-934X(02)00591-6

Kurniasih, K., \& Rahmawati, H. (2018). Developing writing materials based on eclectic approach for Indonesian EFL learners. Metathesis: Journal of English Language, Literature, and Teaching, 2(1), 97. https://doi.org/10.31002/metathesis.v2i1.708

Larsen-Freeman, D. (2000). Techniques and principles in language teaching (Second). https://doi.org/10.2307/3586360

Mediyawati, N., Lustyantie, N., \& Emzir. (2019). M E D I A: Designing a model of IFL learning materials for foreign workers. Cakrawala Pendidikan, 38(1), 75-89. https://doi.org/10.21831/cp.v38i1.22245

Min, H. T. (2009). A Principled eclectic approach to teaching EFL writing in Taiwan. Bulletin of Educational Research, 55(1), 63-95.

Muliastuti, L., Marlina, M., \& Kurniawati, D. (2016). Sahabatku Indonesia: Untuk anak sekolah tingkat A2 (BIPA 2) (A2 ed.). Jakarta: Badan Pengembangan dan Pembinaan Bahasa Kementerian Pendidikan dan Kebudayaan.

Mwanza, D. S. (2017a). Teachers' understanding and attitudes towards the eclectic method to language teaching in Zambia. Journal of Education and Management Studies, 7(1), 1-16.

Mwanza, D. S. (2017b). The Eclectic approach to language teaching: Its conceptialisation and misconceptions. International Journal of Humanities, Social Sciences and Education, 4(2), 53-67. https://doi.org/10.20431/2349-0381.0402006

Najeebullah, N., Tabassum, P. R., \& Irfanullah, I. (2018). Effect of the eclectic approach of teaching on English communication skills at elementary Level. Modern Journal of Language Teaching Methods, 8(2002), 138-146.

Nunan, D. (2004). Task-based language teaching. https://doi.org/10.1017/ CBO9781107415324.004

Obot, I. M., \& Essien, E. E. (2014). Philosophical issues in eclectic approaches to teaching and learning. Education for Today, 10(September), 44-51.

Popova, D. (2001). Eclecticism in foreign language teaching. Greta, 9(2), 35-37. Retrieved from File in Bibliography/Popova

Richards, J., \& Rodgers, T. (2001). Approaches and methods in language teaching. In Cambridge University Press. https://doi.org/10.1016/0346-251X(87)90017-0

Rifa'i, A. (2015). Implementasi Thariqah Al Intiqaiyyah ( Metode Eklektik ) pada 
pembelajaran bahasa Arab di MtsN Kediri 1. Realita, 13(2), 162-172.

Sik, K. (2015). Tradition or modernism in grammar teaching: Deductive vs. inductive approach. 7th World Conference on Educational Sciences, 2141-2144. Athens: Elsevier Ltd.

Suleman, Q., \& Hussain, I. (2016). Effects of eclectic learning approach on students' academic achievement and retention in English at elementary level. Journal of Education and Practice, 7(16), 32-37. Retrieved from http://search.ebscohost.com/login.aspx? direct=true $\& \mathrm{db}=$ eric $\& \mathrm{AN}=\mathrm{EJ} 1105268 \&$ site $=$ ehost-live

Suparman, L. (2017). The Effectiveness of eclectic method in teaching writing English of recount text for the eight grade students of SMPN 1 Keruak. Palapa, 5(1), 4360. https://doi.org/10.36088/palapa.v5i1.35

Suyitno, I., Susanto, G., Kamal, M., \& Fawzi, A. (2017). Cognitive learning strategy of BIPA students in learning the Indonesian language. IAFOR Journal of Language Learning, 3(2), 175-190.

Tiawati, R. L. (2016). Bahasa Indonesia di Thailand menjadi media diplomasi kebahasaan dan budaya di ASEAN melalui pengajaran BIPA. JURNAL GRAMATIKA Jurnal Penelitian Bahasa Dan Sastra Indonesia, 1(1), 29-44. https://doi.org/22202

Wali, N. H. (2009). Eclecticism and language learning. Al-Fatih, 1(39), 34-41. Retrieved from https://iasj.net/iasj?func=fulltext\&aId=17561

Williams, M., \& Burden, R. L. (2007). Psychology for Language Teachers: A Social constructivist approach. Cambridge: Cambridge University Press.

Xiao-yun, Y., Zhou, Z., \& Dai, P. (2007). Principled eclecticism in college English teaching in China. Asian EFL Journal, 17(January), 1-38. 